\title{
Effect of intraperitoneal and intramuscular injection of killed aeromonas hydrophila on lymphocytes and serum proteins of common carp, cyprinus carpio
}

\author{
Rahim Peyghan*, Gholamhosain H. Khadjeh, Naghmeh Mozarmnia, Maryam Dadar
}

Veterinary Faculty, Shahid Chamran University, Ahvaz, Iran.

Email: peyghan_r@cua.ac.ir; rpeyghan@yahoo.com

Received 13 January 2010; revised 20 January 2010; accepted 25 January 2010.

\begin{abstract}
The effects of injectable killed Aeromonas hydrophila on lymphocyte populations and on serum proteins of juvenile common carp, Cyprinus carpio, were examined. The fishes were injected either intraperitoneally or intramuscularly with killed $\boldsymbol{A}$. hydrophila bacterin isolated from a diseased fish. 15 days after injection the lymphocyte count was significantly higher in the kidney of intraperitoneally bacteria injected fishes than in the normal saline injected fishes $(p<0.05)$, but in the blood smears the lymphocyte count difference was not significant $(p>0.05)$. In the intramuscular bacteria injected fishes in comparison with the normal saline group, the lymphocyte count was significantly higher only in the blood $(p<0.05)$ but in the kidney the difference was not significant $(p>$ 0.05). In comparison between the serum protein parameters in different groups, in intraperitoneal injection of killed-bacteria, total albumin as well as the ratio of albumin/globulin was greater than the control group $(p<0.05)$. The other fractions had not showed any significant difference $(p>0.05)$. In intramuscular injection, the normal saline-injected group, amount of al-globulin was significantly higher than bacteria-injected group $(p<0.05)$. For the other fractions there was no significant difference between two groups $(p>0.05)$.
\end{abstract}

Keywords: Aeromonas hydrophila; Globulins; Albumin, Lymphocytes; Vaccination

\section{INTRODUCTION}

Aeromonas hydrophila has been recovered from a wide range of freshwater aquarium and cultured fish species worldwide [1,2]. These bacteria have been associated with tail and fin rot, hemorrhagic septicemia and epizootic ulcerative syndrome in many fish species [1,3]. $A$. hydrophila has also been described as the dominant in- fectious agent of 'fish-bacterial-septicemia' in freshwater cultured cyprinid fishes, mainly common carp.

At present, the chief means of controlling the diseases caused by $A$. hydrophila is by antibiotic treatment and improvement of management practices. However, the extensive use of antibiotics has led to an increase in antibiotic resistance in $A$. hydrophila [4]. An alternative to prophylactic antibiotics treatment is the use of vaccine to prevent the disease. At present no vaccine against $A$. hydrophila is commercially available [5]. Most investigations on fish vaccines development have been carried out mainly on salmonids. These experiments have mostly been based on antibody production and antibodies have been detected in experiments carried out on fish immunized with $A$. hydrophila antigens [6]. However, antibodies have not been detected in some experiments carried out with carp immunized with $A$. hydrophila antigen and several reports have stressed that $A$. hydrophila antigens stimulate non-specific immune mechanisms in fish resulting in cross-immunity against various strains belonging to the genus Aeromonas $[7,8]$.

There have been only a few investigations on vaccination of carp with A. hydrophila [9] and no report observed on effect of vaccination with Aeromonas on lymphocyte proliferation and serum proteins in common carp. Lymphocytes through cell-mediated immunity also play an important role in teleost fish immunity against the bacterial pathogens. In blue gourami, Trichogaster trichopterus the proliferative response of head kidney leucocytes were observed after injection of killed $A$. hydrophila [5]. In this study the effects of injectable killed Aeromonas hydrophila on blood and kidney lymphocytes proliferation of common carp, have been determined and the changes in serum proteins have also been studied.

\section{MATERIAL AND METHODS}

\subsection{Source of Experimental Fish}

120 common carp weighed 30-70 g, were purchased 
from a commercial fish farm, and placed into 12 large, 1001 aquaria in de-chlorinated tap water (water temperature, $22-24^{\circ} \mathrm{C}$; hardness, $368 \mathrm{mg} / 1$ as $\mathrm{CaCO}_{3} ; \mathrm{pH}$, 7.6). The fish were fed once daily and mortality or disease sign was seen during the experiments period in the fish.

\subsection{Bacterin Preparation}

The Aeromonas hydrophila bacterin was prepared as follows in our laboratory. The bacterium was isolated and had been identified previously from a diseased common carp. The bacterin was prepared from an isolate grown for $24 \mathrm{~h}$ at $25^{\circ} \mathrm{C}$ in nutrient agar and by washing with phosphate buffered saline (PBS). Cells were then suspended in PBS containing $0.3 \%$ formalin to a final concentration of $900 \times 10^{6}$ cells ml-1 . To test for sterility, $0.1 \mathrm{ml}$ of the each suspension were streaked on blood agar and incubated for 48 hour at $25^{\circ} \mathrm{C}$.

\subsection{Vaccination}

The fishes were randomly selected and separated to 4 groups. Two groups of 30 fish each were immunized by intramuscular (I.M.) and intraperitoneal (I.P.) injection, with formalin-killed whole culture cells of Aeromonas hydrophila ( $0.5 \mathrm{ml}$ of bacterin solution in each fish). 40 other fish were separated into 2 groups. 20 fish were injected with $0.5 \mathrm{ml}$ normal saline solution intraperitoneally and 20 fish intramuscularly (controls).

\subsection{Sampling and Lymphocyte Counting}

Blood samples were taken from the caudal vein without anticoagulant. From each blood sample, one drop was quickly smeared on to a glass slide for counting of lymphocytes. Blood smears were fixed with methanol immediately after drying. After euthanasia of fish by severance of the spinal cord just behind the opercula, the uppermost abdominal body wall was removed and a thin smear from the head kidney was also prepared. All smears were stained by Giemsa method and lymphocytes were counted in relation with counting 1000 RBC, in blood and hematopoietic tissue of anterior kidney of all groups 15 days post-injection by light microscopy.

\subsection{Serum Electrophoresis}

15 days after injection the serum protein fractions of blood were studied by gel electrophoresis method. Serum was separated by storing the blood in $4^{\circ} \mathrm{C}$ for 30-60 min and centrifugation at $2000 \mathrm{rpm}$ for $30 \mathrm{~min}$. Total serum protein was determined by Biuret reaction using an automated biochemical analyzer (Elan, Eppendorf, Germany). Protein fractions were separated electrophoretically by agarose gel [Sebia Hydragel Protein (E) K20], using manufacturer's suggested procedure. Briefly, $10 \mu \mathrm{l}$ of the serum sample was applied to the agarose gel plate and the plate was placed into an electrophoresis chamber (Sebia K20) with buffer solution ( $\mathrm{pH} 8.5 \pm 0.3)$ and was processed for $22 \mathrm{~min}$ at $90 \mathrm{v}$. Immediately after the electrophoresis, the fractionated proteins were fixed (fixative solution: $60 \%$ ethanol, $10 \%$ acetic acid and $30 \%$ deionized water) and stained in amidoblack solution for $4 \mathrm{~min}$. After staining, the gel was decolorized, dried, and scanned by use of a densitometer (Sebia K20) and the calculation of various protein fractions was made from the resultant electrophoregram.

\subsection{Statistical Analysis}

For statistical analysis, means and standard deviations for all test values were calculated and one-way ANOVA test (Analysis of Variance) was used to determine whether differences existed between the means were significant or not.

\section{RESULTS}

The lymphocyte count in all experimental groups was higher than the control groups. The statistical analysis of data (Table 1) showed that, the lymphocyte counts were significantly higher in the kidney of intraperitoneal bacterin injected fishes than the normal saline injected fishes $(\mathrm{p}<0.05)$, but in the blood the difference was not significant $(p>0.05)$. In the intramuscular bacteria injected fishes in comparison with the normal saline group, the lymphocytes count were significantly higher only in the blood $(\mathrm{p}<0.05)$ and in the kidney the difference was not significant $(p>0.05)$. In both blood and kidney, the relative lymphocytes count were in I.M. injected group were significantly higher than I.P. injected group $(\mathrm{p}<$ 0.05).

Electrophoretogram of experimental and control groups indicated a pattern consisting of 6 peaks. According to other vertebrates' electrophoretogram pattern, from anode to cathode, the picks were named as prealbumin, albumin, $\alpha_{1}$-globulin, $\alpha_{2}$-globulin, $\beta$-globulin, $\gamma$-globulin and in some cases $\gamma_{2}$-globulin.

The results showed that in intraperitoneal injection of killed bacteria, total albumin as well as the ratio of albumin/globulins (A/G) was significantly greater than the control group. The other fractions had not showed any significant difference.

In intramuscular injection, normal saline injected group amount of $\alpha_{1}$-globulin, was significantly higher than bacteria injected group $(\mathrm{p}<0.05)$. For other fractions there was no significant difference between two groups (Table 2).

\section{DISCUSSION}

Despite the extensive reported works on teleost immunology there are a little reports on serum component and cellular antibacterial defense mechanisms in common carp, maybe due to the lack of investigation in this field. 
Table 1. Lymphocyte count in blood and kidney of common carp after bacterin and normal saline injection.

\begin{tabular}{ccccc}
\hline \multirow{2}{*}{ Group } & \multicolumn{2}{c}{ Blood lymphocytes $^{1}$} & \multicolumn{2}{c}{ Kidney lymphocytes $^{2}$} \\
\cline { 2 - 5 } & $\begin{array}{c}\text { Bacterin } \\
(\mathrm{n}=30)\end{array}$ & $\begin{array}{c}\text { Normal saline } \\
(\mathrm{n}=20)\end{array}$ & $\begin{array}{c}\text { Bacterin } \\
(\mathrm{n}=30)\end{array}$ & $\begin{array}{c}\text { Normal salin } \\
(\mathrm{n}=20)\end{array}$ \\
\hline I.M. injection & $56.27 \pm 24.51^{\mathrm{a}_{\mathrm{n}}}$ & $26.5 \pm 9.79^{\mathrm{a}}$ & $38.48 \pm 12.05^{\mathrm{n}}$ & $33.7 \pm 11.05$ \\
I.P. injection & $36.97 \pm 22.11^{\mathrm{n}}$ & $35.2 \pm 22.49$ & $33.05 \pm 14.71^{\mathrm{an}_{\mathrm{n}}}$ & $23.8 \pm 10.99^{\mathrm{a}}$ \\
\hline
\end{tabular}

a- The difference between experimental and control group was significant $(\mathrm{p}<0.05)$

${ }^{n}$ - The difference between two experimental group was significant $(\mathrm{p}<0.05)$

1. Number of lymphocyte in relation with counting 1000 RBC

${ }^{2}$ - Number of lymphocyte in relation with counting 1000 RBC

Table 2. Different fractions of serum proteins in experimental and control groups (Mean $\pm \mathrm{SD}$ ).

\begin{tabular}{|c|c|c|c|c|}
\hline \multirow{2}{*}{$\begin{array}{c}\text { Groups } \\
\text { Parameters }\end{array}$} & \multicolumn{2}{|c|}{ I.P. injection } & \multicolumn{2}{|c|}{ I.M. injection } \\
\hline & $\begin{array}{l}\text { Bacterin } \\
(\mathrm{n}=30)\end{array}$ & $\begin{array}{l}\text { Normal saline } \\
\quad(\mathrm{n}=20)\end{array}$ & $\begin{array}{l}\text { Bacterin } \\
(\mathrm{n}=30)\end{array}$ & $\begin{array}{l}\text { Normal saline } \\
(\mathrm{n}=20)\end{array}$ \\
\hline Total protein $(\mathrm{g} / \mathrm{dl})$ & $3.76 \pm 0.49$ & $3.63 \pm 0.36$ & $3.57 \pm 0.35$ & $3.88 \pm 0.75$ \\
\hline Pre-albumin (g/dl) & $0.23 \pm 0.12$ & $0.19 \pm 0.09$ & $0.21 \pm 0.07$ & $0.28 \pm 0.12$ \\
\hline Albumin $(\mathrm{g} / \mathrm{dl})^{*}$ & $1.97 \pm 0.37 *$ & $1.81 \pm 0.32 *$ & $1.92 \pm 0.31$ & $1.98 \pm 0.48$ \\
\hline$\alpha$ 1- globulin* $(\mathrm{g} / \mathrm{dl})$ & $0.5 \pm 0.2$ & $0.48 \pm 0.15$ & $0.47 \pm 0.09^{*}$ & $0.59 \pm 0.17^{*}$ \\
\hline$\alpha 2-$ globulin $(\mathrm{g} / \mathrm{dl})$ & $0.67 \pm 0.16$ & $0.55 \pm 0.3$ & $0.6 \pm 0.1$ & $0.6 \pm 0.13$ \\
\hline$\beta$-globulin $\quad(\mathrm{g} / \mathrm{dl})$ & $0.21 \pm 0.17$ & $0.27 \pm 0.31$ & $0.27 \pm 0.11$ & $0.22 \pm 0.1$ \\
\hline$\gamma$-globulin $(\mathrm{g} / \mathrm{dl})$ & $0.21 \pm 0.2$ & $0.34 \pm 0.25$ & $0.11 \pm 0.06$ & $0.15 \pm 0.1$ \\
\hline Total globulin (g/dl) & $1.6 \pm 0.33$ & $1.69 \pm 0.36$ & $1.44 \pm 0.23$ & $1.62 \pm 0.35$ \\
\hline Albumin/globulin ratio* & $1.49 \pm 0.53^{*}$ & $1.15 \pm 0.49^{*}$ & $1.51 \pm 0.35$ & $1.41 \pm 0.33$ \\
\hline
\end{tabular}

*- The difference between groups was significant $(\mathrm{p}<0.05)$

In immune parameter studies in many investigations, it has been appeared that production of specific antibodies and lymphocytes, responded well to the bacterial vaccines [1]. Enhancement of protective specific immunity maybe reflected as a result of changing in serum protein composition. Our results showed that in intra-peritoneal injection of killed bacteria, total albumin as well as the ratio of albumin/globulins was significantly greater than the control group. Because of the high osmotic pressure produced by albumin relatively low molecular weight and rather high concentration in the blood stream, the albumin fraction exerts more influence on plasma volume than any other plasma protein. Hence, condition of hyperalbuminemia is rarely seen except in the presence of acute dehydration and shock. Although certain pathological conditions that may lead to hypoalbuminemia in control are: deficient intake of protein, deficient synthesis of albumin by liver and or excessive breakdown or loss of albumin. In intramuscular bacterin injected group the amount of 1-globulin, was significantly lower than the control group. In the 1-globulin fraction are some of the small lipoproteins, some enzymes, mucoproteins and factor V. Further works need to be carried out to determine in more detail, which protein of $\alpha$-globulin group has been decreased in response to the bacterin injection. In our experiments the $\gamma$-globulin fraction didn't change significantly. The $\gamma$-globulin fraction contains the anti bodies. In fish, antibody production in the presence of antigen depends greatly on water temperature and in lower temperature it need more time to rise to significant level. So in our experiment if the experiment continued to 1 month the $\gamma$-globulin change might raise significantly. Some studies on serum composition in Atlantic salmon infected with A. salmonicida have shown that, some of indices such as total protein and $\gamma$-globulin fraction increased significantly $[10,11]$. On the other hand, Evenberg and his co-workers [12] found that the total serum protein and $\gamma$-globulin level was greatly reduced in carp experimentally infected with $A$. salmonicida.

According to our results, method of injection technique may influence the immune response of the fish to vaccination. Many researchers have found that injection is a more reliable method of vaccination compared with the oral or topical application of vaccines against Aeromonas infections. Indian carps and tilapia immunized either intramuscularly or intraperitoneally with Aeromonas vaccine, showed protection against challenge and the agglutinating antibody titre increased in the serum of immunized fish $[13,14]$. Catfish immunized intraperitoneally by injection with the acid extract of the S-layer protein of $A$. hydrophila were protected from the homologous, virulent strain [15]. In the study of the effects of inject able vaccines against Aeromonas salmonicida in rainbow trout, the greatest and broadest ranges of responses were caused by the microencapsulated bacterin with $V$. anguillarum LPS [16].

The experiment with juvenile common carp presented in this paper showed that in comparison with the control, 
lymphocytes count has been altered significantly after vaccination. The increase in the number of peripheral blood and kidney lymphocytes that observed in our experimental groups expectedly may be correlated with development of anti-Aeromonas cell mediated immunity in the vaccinated fish. However, for confirmation of effectiveness of the method, changing in other immune parameter such as production of specific antibodies and challenging the fish with a virulent Aeromonas strains must be examined. Further more for the better results, many other factors such as, using immune-stimulators, the choice of the bacterial strains, fish age and water temperature also must be taken into consideration.

\section{REFERENCES}

[1] Austin, B. and Adams, C. (1996) Fish pathogens. In: Austin, B., Altwegg, M., Gosling, P.J. and Joseph, S. (Eds) The Genus Aeromonas, John Wiley and Sons, Chichester, pp. 197-243.

[2] Nielsen, M.E. Schmidt, A. Qian, D. Shimada, T. Shen, J.Y. and Larsen, J.L. (2001) Is Aeromonas hydrophila the dominant motile Aeromonas species that causes disease outbreaks in aquaculture production in the Zhejiang province of China. Disease of Aquatic Organisms, 46, 23-29.

[3] Roberts, R.J. (1997) Epizootic ulcerative syndrome (EUS): progress since 1985. In: Flegel T.W. and MacRae I.H. (Eds) Diseases in Asian aquaculture III. Asian Fisheries Society, Manila, pp. 125-128

[4] Ansary, A., Haneef, R.M., Torres, J.L. and Yadav, M. (1992) Plasmids and antibiotic resistance in Aeromonas hydrophila, isolated in Malaysia from healthy and diseased fish. Journal of Fish Diseases, 15, 191-196.

[5] Fang, H.M., Ling, K.C., Ge, R. and Sin. Y.M. (2000) Enhanchment of productive immunity in blue gourami, Trichogaster trichopterus (Pallas), against Aeromonas hydrophila and Vibrio anguillarum by A. hydrophila major adhesion. Journal of Fish Diseases. 23, pp. 137-145.

[6] Loghothetis, P.N. and Austin, B. (1994) Immune response of rainbow trout (Oncorhynchus mykiss, Walbaum) to Aeromonas hydrophila. Fish and Shell Fish Immunology, 4(23), 254.
[7] Baba, T., Imamura, J. and Izawa, K. (1988) Immune protection in carp, Cyprinus carpio L., after immunization with Aermonas hydrophila crude lipopolysaccharide. Journal of Fish Diseases, 11, 237-244.

[8] Stevenson, R.M.W. (1988) Vaccination against Aeromonas hydrophila. In: Ellis, A.E. (Ed.), Fish Vaccination, Academic Press, London, pp. 112-123.

[9] Kozinska, A. and Guz, L. (2004) The effect of various Aeromonas bestiarum vaccines on non-specific immune parameters and protection of carp (Cyprinus carpio L.). Fish and Shellfish Immunology, 16, 437-445.

[10] Magnadottir, B. and Gudmundsdottir, B.K. (1992) A composition of total and specific immunoglobulin levels in healthy Atlantic salmon (Salmo salar, L.) and in salmon naturally infected with Aeromonas salmonicida sub sp. Veterinary Immunology and Immunopathology, 32, 179-189.

[11] Moyner, K. (1993) Changes in serum protein composition occur in Atlantic salmon, Salmo salar L. during Aeromonas salmonicida infection. Journal of Fish Diseases. 16: 6. 601-604.

[12] Evenberg, D., de Graaff, P., Fleuren, W. and van Muiswinkel, W.B. (1986) Blood changes in carp (Cyprinus carpio) induced by ulcerative Aeromonas salmonicida infections. Veterinary Immunology and Immunopathology, 12, 321-330.

[13] Ruangapan, L., Kitao, T. and Yoshida, T. (1986) Protective efficacy of Aeromonas hydrophila vaccine in Nile tilapia. Veterinary Immunology and Immunopathology, 12, 345-350.

[14] Karunasagar, I., Rosalind, G. and Karunasagar, I. (1991) Immunological response of the Indian major carps to Aeromonas hydrophila vaccine. Journal of Fish Diseases, 14, 413-417.

[15] Ford, L.A. and Thune, R.L. (1992) Immunization of channel catfish with a crude, acid extracted preparation of motile aeromonad S-layer protein. Biochemical Letters, 47, 335-362.

[16] Ackerman, P.A., Iwama, G.K. and Thornton, J.C. (2000) Physiological and immunological effect of adjuvanted Aeromonas salmonicida vaccines on juvenile rainbow trout. Journal of Aquatic Animal Health, 12(2), 157-164. 